\title{
Dietary habits and per-meal protein intake among older adults: Associations with visceral proteins
}

\author{
Linda Kornstad Nygård ( $\square$ linda.nygard@himolde.no) \\ Hogskolen i Molde https://orcid.org/0000-0002-6317-5516 \\ Lisbeth Dahl \\ Institute of Marine Research: Havforskningsinstituttet \\ Ingunn Mundal \\ Høgskolen i Molde: Hogskolen i Molde \\ Anne Marie Mork Rokstad \\ Høgskolen i Molde: Hogskolen i Molde
}

\section{Research}

Keywords: Protein, Nutrition, Elderly, Meal, Protein distribution, Albumin, Prealbumin, Retinol-binding protein

Posted Date: March 2nd, 2021

DOI: https://doi.org/10.21203/rs.3.rs-235287/v1

License: (c) (i) This work is licensed under a Creative Commons Attribution 4.0 International License. Read Full License 


\section{Abstract}

Background: There is emerging evidence that per meal intake of protein might influence the anabolic effects of protein intake. Visceral proteins are commonly used as biomarkers of protein nutrition status. However, associations between visceral proteins and different aspects of protein intake, like per meal intake and protein sources, are rarely examined.

Method: In a cross-sectional study of 92 adults aged 65 years or older protein intake (all day, breakfast, lunch, dinner and evening meal) and number of meals with $\geq 30 \mathrm{~g}$ protein were assessed by a $24 \mathrm{~h}$ multiple pass method. Dietary habits were assessed by a frequency questionnaire, and nutritional status by the Mini Nutritional Assessment (MNA). Blood samples were analyzed for serum albumin, pre-albumin and retinolbinding protein (RBP), and associations with nutrition assessed with correlation analyses and t-tests for difference between groups.

Result: More than one meal with $\geq 30 \mathrm{~g}$ protein was reported by $10 \%$ of the participants, and $28 \%$ of the participants did not reach an intake of $30 \mathrm{~g}$ in any of their meals. Albumin, prealbumin and RBP was not associated with protein intake in total or per meal.

Further, the biomarkers were not significantly different compared to participants with at least one meal with $\geq 30 \mathrm{~g}$ protein.

Conclusions: This study demonstrated infrequent intake of meals with $\geq 30 \mathrm{~g}$ protein and no associations with biomarkers. Larger studies should assess per meal intake of protein to gain knowledge of possible health effects of protein eating patterns in elderly.

\section{Trial registration}

This study report baseline assessments from a randomised controlled study pre-registered at http://www.clinicaltrials.gov with the unique identifier NCT02890290.

\section{Background}

Nutritional changes during ageing, often viewed as the so-called 'anorexia of ageing', alter body composition and metabolism in ways that can decrease the need for and intake of energy [1]. Other aspects of ageing-for instance, low physical activity, pain and/or discomfort, gastrointestinal changes, swallowing difficulties and poor dental status-can also affect food intake [2]. Social networks are also of importance for maintaining health and physical function [3], and the feeling of loneliness is associated with malnutrition [4]. Thus, the loss of social relations (e.g. living alone instead of with one's family) may affect food intake. Beyond that, the loss of physical function, psychological health problems, and cognitive decline among older adults can affect their ability to prepare food. A shift to consumption of readymade food, is associated with the risk of insufficient protein intake [5]. Decreased intake and energy requirements may make it harder to get sufficient amounts of nutrients [2]. Although older adults indeed have decreased energy requirements, their need for some nutrients, including protein, increases. The recommended protein intake for older adults (i.e. $\geq 65$ years) is $15-20 \%$-that is, approximately 1.1 to $1.3 \mathrm{~g}$ of protein per kilogram of body weight per day [6]. 
Although increased protein intake has been associated with increased physical performance and muscle strength in some studies, the findings remain inconsistent [7]. Bollwein et al. [8], for instance, found that the distribution of protein during the day, and not the total protein intake per day, was associated with frailty. Other studies have shown no associations between protein distribution and physical function or strength [9, 10]. However, meal-specific protein dose may have biased findings in studies assessing protein distribution. Some studies have pinpointed a threshold of protein intake needed to stimulate muscle protein synthesisapproximately $20 \mathrm{~g}$ per meal-although the necessary amount seems to be greater (i.e. $30-40 \mathrm{~g}$ ) for older adults [11]. Gaytán-González et al. [12] found that eating at least two meals per day with at least $30 \mathrm{~g}$ of protein was associated with a lower risk of disability in activities of daily living among older adults in Mexico.

Another aspect affecting the health benefits of protein is the protein quality, i.e. the amino acid content and digestibility [13]. For example, animal proteins have a more complete amino acid profile than plant proteins $[14,15]$, and fish proteins are liable to have different properties from those in meat from other animals [16]. According to the Norkost 3 study, sources of protein among adults in Norway include meat $(27 \%$ of total protein intake), bread $(18 \%)$, fish $(11 \%)$, milk or yoghurt $(11 \%)$, cheese $(10 \%)$ cereal products $(4 \%)$, and eggs (3\%) [17]. Meat and fish are traditionally eaten at dinner in Norway, whereas breakfast and lunch more often include bread, milk or yoghurt, cheese and eggs.

Nutritional status can be assessed by using screening tools, anthropometric measures and various biomarkers. In particular, visceral plasma proteins-for example, albumin, prealbumin and retinol-binding protein (RBP) -have been regarded important for assessing malnutrition of protein status [18].

The aim of our study was to describe protein intake, patterns of protein intake during meals, sources of protein and biomarkers of protein among older adults $\geq 65$ years old.

\section{Methods}

The present study report baseline assessments from a randomised controlled study exploring the health effects of marine proteins. The study's design has previously been described in a protocol article published in BMJ Open [19]. Recruitment took place between March 2017 and May 2018 by municipality health care nurses, local media, at talks and with flyers placed at associations for older adults. Inclusion criteria was being 65 years or older. Subjects with diabetes, kidney failure, progressive muscle disease or active cancer were excluded from participating in the study. Data were collected during structured interviews, tests and anthropometric measurements performed in the participants' homes by the first author, whereas blood samples were taken by each participant's medical practitioner. Background data such as age, gender, habitation status (i.e. living alone or not) and level of education were collected using standardised protocols. Level of education was dichotomised into those with and without higher education (at university or college level). Body weight and height were recorded, and body mass index (BMI) was computed as $\mathrm{kg} / \mathrm{m}^{2}$. BMI between 22.0 and 27.0 is recommended for older adults in Norway's national guidelines [20].

\section{4-h recall of dietary intake}


Dietary intake of protein and energy were assessed with one 24-h recall following the multiple-pass method described in the Newcastle 85 + study [21]. Dietary intake of energy and protein per meal and in total were calculated by entering the reported foods in a Norwegian diet tool (kostholdsplanleggeren.no). As part of the multiple-pass method, meals were categorised as breakfast, lunch, dinner and evening meal. Based on the concept of per meal requirements of protein [11, 12], number of participants who consumed $30 \mathrm{~g}$ of protein per meal was identified. We also asked participants whether the day that they reported was a typical day regarding amount of food eaten.

\section{Frequency of protein sources}

On a brief questionnaire about the frequency of consuming certain foods, participants reported how often they consume bread or crispbread (i.e. number of slices or pieces per day), eggs (i.e. $<1,1,2-3,4-5,6-7$ or $\geq$ 8 eggs per week) and milk, yoghurt or cheese (i.e. $<1,1-3$ or $4-6$ portions per week or 1,2 or $\geq 3$ portions per day). They also reported how often they ate a warm dinner and how often they chose meat, fish or vegetarian alternatives for dinner (i.e. $0,<1$ or $1-3$ times per month or $1,2-3,4-5$ or $6-7$ times per week). Participants were instructed to report an average frequency with reference to the past 6 months.

\section{Nutritional status}

The MNA is commonly used in clinical work and research around the world [22] and recommended by the Norwegian Directorate of Health to assess nutritional status in older adults [20]. Based on answers to questions about nutrition, weight development and other risk factors of malnutrition, the MNA categorises individuals by nutritional status as not at risk of malnutrition, at risk of malnutrition or having malnutrition. With reliability and validity firmly established across care settings, the full MNA has a sensitivity of $96 \%$ and specificity of $98 \%$ relative to clinical status [22].

\section{Biomarkers}

Participants visited their medical practitioners for the blood sampling. Biomarkers of protein malnutrition albumin, prealbumin and RBP were determined in the belonging hospital laboratory [23]. In addition, Creactive protein (CRP) was included to identify inflammation.

\section{Statistical analysis}

Descriptive variables, energy intake and protein intake from 24-h recall and biomarker values are presented as mean $\pm S D$ or $n(\%)$ as appropriate. Frequency of intake of protein-rich foods are presented as median frequencies and $n(\%)$ reporting different frequencies. The independent samples $t$ test was used to assess differences in energy intake and protein intake among participants who reported the day of 24-h recall to be typical and ones who did not.

The relationships between protein intake (i.e. all day, breakfast, lunch, dinner and evening meal) and biomarkers (i.e. albumin, prealbumin and RBP) were investigated using Pearson's correlation coefficient. Preliminary analyses were performed to ensure that no violations of the assumptions of normality, linearity and homoscedasticity occurred. 
The independent samples $t$ test was also used to assess differences in biomarker levels between participants who ate zero versus $\geq 1$ meal with $\geq 30 \mathrm{~g}$ of protein, between participants with a high or low intake of proteinrich foods (i.e. with the median intake frequency used as the cut-off) and between participants at risk of malnutrition (i.e. according to the MNA) or not.

To account for possible effects of inflammation on visceral proteins, a sensitivity analysis was performed by repeating the analysis with and without participants with CRP levels exceeding $5.0 \mathrm{mg} / \mathrm{L}$, both in correlations of biomarkers with protein intake and $t$ test's assessing differences related to the frequency of consuming different protein-rich foods.

All statistical analyses were performed with IBM- SPSS version 27.0. Results with $p$ values less than .05 were considered to be statistically significant.

\section{Results}

A total of 92 participants aged 65 to 93 years consented to participate in our study. Baseline characteristics of the study population are given in Table 1. Participants had a mean age of $73.8 \pm 8.9$ years; 61 of them $(66 \%)$ were women, 34 (37\%) were living alone, and 41 (44\%) had higher education, and the mean BMI was 26 $\mathrm{kg} / \mathrm{m}^{2}$.

Table 1

Characteristics of all participants $(n=92)$, participating women and participating men

\begin{tabular}{|llll|}
\hline & All & Women $(n=61,66 \%)$ & Men $(n=31,34 \%)$ \\
\hline Age (years), mean $\pm S D$ & $73.8 \pm 8.9$ & $72.2 \pm 8.3$ & $74.2 \pm 8.9$ \\
\hline Weight $(\mathrm{kg})$, mean $\pm S D$ & $74.0 \pm 14.7$ & $70.6 \pm 13.8$ & $82.8 \pm 13.3$ \\
\hline BMI $\left(\mathrm{kg} / \mathrm{m}^{2}\right)$, mean $\pm S D$ & $26.3 \pm 4.9$ & $26.3 \pm 4.8$ & $26.4 \pm 3.9$ \\
\hline Have higher education, $n(\%)$ & $41(44)$ & $28(45.9)$ & $13(41.9)$ \\
\hline Live alone, $n(\%)$ & $34(37)$ & $30(49.2)$ & $4(12.9)$ \\
\hline
\end{tabular}

Participants who reported that the day of 24-h recall was atypical regarding the amount of food eaten $(n=10)$ had significantly less energy intake (mean diff. $=-400 \mathrm{kcal}, p=.025)$ and protein intake (mean diff. $=-23.5 \mathrm{~g}$, $p=.002$ ) than the others. Thus, we excluded those participants from analyses involving the 24 -h recall. Energy intake, total protein intake, protein intake per meal and number of participants who reported eating at least $30 \mathrm{~g}$ of protein per meal appear in Table 2. Whereas 28 (35\%) participants did not eat $30 \mathrm{~g}$ of protein during any meal, $44(55 \%)$ ate $30 \mathrm{~g}$ during at least one meal, and eight $(10 \%)$ consumed two or three meals with more than $30 \mathrm{~g}$ of protein. 
Table 2

Energy and protein intake calculated from one 24-h recall $(n=80)^{1}$

\begin{tabular}{|c|c|c|c|c|}
\hline Intake & $\begin{array}{l}\text { All } \\
(\text { mean } \pm S D)\end{array}$ & $\begin{array}{l}\text { Women } \\
\text { (mean } \pm S D)\end{array}$ & $\begin{array}{l}\text { Men } \\
\text { (mean } \pm S D)\end{array}$ & $\begin{array}{l}>30 \mathrm{~g} \text { of protein } \\
n(\%)^{2}\end{array}$ \\
\hline Energy (kcal) & $\begin{array}{l}1849 \pm 530 \\
(n=80)\end{array}$ & $\begin{array}{l}1771 \pm 536 \\
(n=54)\end{array}$ & $\begin{array}{l}2012 \pm 489 \\
(n=26)\end{array}$ & \\
\hline Protein, total (g) & $\begin{array}{l}78.1 \pm 21.7 \\
(n=80)\end{array}$ & $\begin{array}{l}73.5 \pm 22.5 \\
(n=54)\end{array}$ & $\begin{array}{l}87.5 \pm 16.6 \\
(n=26)\end{array}$ & \\
\hline Protein, breakfast (g) & $\begin{array}{l}17.6 \pm 8.2 \\
(n=80)\end{array}$ & $\begin{array}{l}17.6 \pm 7.3 \\
(n=54)\end{array}$ & $\begin{array}{l}18.2 \pm 10.1 \\
(n=26)\end{array}$ & $7(8.5 \%)$ \\
\hline Protein, lunch (g) & $\begin{array}{l}15.2 \pm 9.3 \\
(n=56)\end{array}$ & $\begin{array}{l}13.0 \pm 8.1 \\
(n=40)\end{array}$ & $\begin{array}{l}20.9 \pm 9.9 \\
(n=16)\end{array}$ & $4(4.9 \%)$ \\
\hline Protein, dinner (g) & $\begin{array}{l}35.3 \pm 15.1 \\
(n=79)\end{array}$ & $\begin{array}{l}33.5 \pm 15.1 \\
(n=53)\end{array}$ & $\begin{array}{l}38.9 \pm 14.8 \\
(n=26)\end{array}$ & $48(58.5 \%)$ \\
\hline Protein, evening meal (g) & $\begin{array}{l}13.1 \pm 8.2 \\
(n=58)\end{array}$ & $\begin{array}{l}12.1 \pm 8.0 \\
(n=38)\end{array}$ & $\begin{array}{l}14.9 \pm 8.4 \\
(n=20)\end{array}$ & $2(2.4 \%)$ \\
\hline
\end{tabular}

Results for visceral protein in serum appear shown in Table 3. One participant had prealbumin levels below the reference range given by the laboratory, while nine had RBP levels exceeding its reference range. 
Table 3

Concentrations of albumin, prealbumin, $\mathrm{RBP}^{1}$ and $\mathrm{CRP}^{2}$ in serum samples

\begin{tabular}{|c|c|c|c|c|c|}
\hline & Ref. $^{3}$ & All $^{4}$ & Women & Men & Min.-max. \\
\hline \multirow[t]{2}{*}{ Albumin (g/L) } & $39.0-50.0$ & $44.2 \pm 2.5$ & $44.2 \pm 2.5$ & $44.3 \pm 2.5$ & $39.0-50.0$ \\
\hline & & $(n=80)$ & $(n=51)$ & $(n=29)$ & \\
\hline \multirow[t]{2}{*}{ Prealbumin $(\mathrm{g} / \mathrm{L})$} & $0.2-0.4$ & $0.27 \pm 0.045(n=77)$ & $0.26 \pm 0.04$ & $0.29 \pm 0.05$ & $0.19-0.39$ \\
\hline & & & $(n=48)$ & $(n=29)$ & \\
\hline \multirow[t]{2}{*}{$\operatorname{RBP}(g / L)$} & $0.03-0.06$ & $0.05 \pm 0.01$ & $0.05 \pm 0.01$ & $0.06 \pm 0.01$ & $0.03-0.08$ \\
\hline & & $(n=76)$ & $(n=48)$ & $(n=28)$ & \\
\hline \multirow[t]{2}{*}{$\mathrm{CRP}(\mathrm{mg} / \mathrm{L})$} & $<5.0$ & $2.3 \pm 2.8$ & $2.1 \pm 2.0$ & $2.7 \pm 3.7$ & $0.0-16.0$ \\
\hline & & $(n=79)$ & $(n=50)$ & $(n=29)$ & \\
\hline
\end{tabular}

Correlation coefficients and $p$ values for associations between total protein, protein in each of the four meals and visceral proteins appear in Table 4 . A moderately positive correlation emerged between protein eaten at lunch and $\operatorname{RBP}(r=.30, n=53, p=.029)$, whereas all other correlations were only slightly positive $(r<.30)$. 
Table 4

Correlations between total protein, protein eaten at each of four meals and visceral proteins ${ }^{1}$

\begin{tabular}{|c|c|c|c|c|c|c|c|c|}
\hline & & Breakfast & Lunch & Dinner & $\begin{array}{l}\text { Evening } \\
\text { meal }\end{array}$ & Albumin & Prealbumin & $\mathrm{RBP}^{2}$ \\
\hline \multirow[t]{3}{*}{$\begin{array}{l}\text { Total } \\
\text { protein }\end{array}$} & $\begin{array}{l}\text { Pearson's } \\
\text { correlation }\end{array}$ & $.262^{\star}$ & $.535^{\star}$ & $.669 *$ & $.689 *$ & .003 & .130 & -.025 \\
\hline & $\begin{array}{l}p(2- \\
\text { tailed })\end{array}$ & .040 & .000 & .000 & .000 & .984 & .332 & .853 \\
\hline & $n$ & 62 & 44 & 62 & 45 & 62 & 58 & 56 \\
\hline \multirow[t]{3}{*}{ Breakfast } & $\begin{array}{l}\text { Pearson's } \\
\text { correlation }\end{array}$ & & -.195 & -.222 & $.401 *$ & .111 & .176 & -.087 \\
\hline & $\begin{array}{l}p(2- \\
\text { tailed })\end{array}$ & & .205 & .083 & .006 & .392 & .186 & .525 \\
\hline & $N$ & & 44 & 62 & 45 & 62 & 58 & 56 \\
\hline \multirow[t]{3}{*}{ Lunch } & $\begin{array}{l}\text { Pearson's } \\
\text { correlation }\end{array}$ & & & .272 & .184 & .021 & $.362^{\star}$ & .209 \\
\hline & $\begin{array}{l}p(2- \\
\text { tailed })\end{array}$ & & & .074 & .357 & .890 & .020 & .189 \\
\hline & $N$ & & & 44 & 27 & 44 & 41 & 41 \\
\hline \multirow[t]{3}{*}{ Dinner } & $\begin{array}{l}\text { Pearson's } \\
\text { correlation }\end{array}$ & & & & .221 & -.156 & -.010 & -.001 \\
\hline & $\begin{array}{l}p(2- \\
\text { tailed })\end{array}$ & & & & .145 & .227 & .940 & .992 \\
\hline & $N$ & & & & 45 & 62 & 58 & 56 \\
\hline \multirow[t]{3}{*}{$\begin{array}{l}\text { Evening } \\
\text { meal }\end{array}$} & $\begin{array}{l}\text { Pearson's } \\
\text { correlation }\end{array}$ & & & & & -.074 & -.136 & -.074 \\
\hline & $\begin{array}{l}p(2- \\
\text { tailed })\end{array}$ & & & & & .630 & .395 & .650 \\
\hline & $N$ & & & & & 45 & 41 & 40 \\
\hline \multirow[t]{3}{*}{ Albumin } & $\begin{array}{l}\text { Pearson's } \\
\text { correlation }\end{array}$ & & & & & & $.355^{\star}$ & .239 \\
\hline & $\begin{array}{l}p(2- \\
\text { tailed })\end{array}$ & & & & & & .006 & .076 \\
\hline & $N$ & & & & & & 58 & 56 \\
\hline Prealbumin & $\begin{array}{l}\text { Pearson's } \\
\text { correlation }\end{array}$ & & & & & & & $.699 *$ \\
\hline $\begin{array}{l}{ }^{1} \text { Number of } \\
\text { four meals. }\end{array}$ & $\begin{array}{l}\text { ticipants va } \\
P=\text { retinol- }\end{array}$ & $\begin{array}{l}\text { s due to } \\
\text { ding prot }\end{array}$ & $\begin{array}{l}\text { sing } b \\
\star \text { Sign }\end{array}$ & $\begin{array}{l}\text { d sam } \\
\text { int at }\end{array}$ & $\begin{array}{l}\text { s and be } \\
.05 \text { level }\end{array}$ & $\begin{array}{l}\text { se not a } \\
\text { ailed). }\end{array}$ & articipants & all \\
\hline
\end{tabular}




\section{Breakfast Lunch Dinner Evening Albumin Prealbumin RBP2}

$p(2-$

tailed)

$N$

${ }^{1}$ Number of participants varies due to missing blood samples and because not all participants ate all four meals. ${ }^{2} \mathrm{RBP}=$ retinol-binding protein. ${ }^{*}$ Significant at the .05 level (2-tailed).

Although nine participants had CRP levels of at least $5.0 \mathrm{mg} / \mathrm{L}$, the highest level was $16.0 \mathrm{mg} / \mathrm{L}$. For a sensitivity analysis, a correlation analysis of the relationship between protein intake and biomarkers was repeated but excluding participants with CRP levels of at least $5.0 \mathrm{mg} / \mathrm{L}$. However, the exclusion did not alter the conclusions $(r=.37, n=43, p=.015)$ for the correlation between lunch and RBP. Differences in biomarkers were also assessed between participants with zero versus at least one meal with at least $30 \mathrm{~g}$ of protein. However, no significant differences were found (data not shown).

Eighty-two participants (90\%) reported eating dinner (i.e. a warm meal) every day, and no participants reported skipping dinner more than 1-3 d per week. Two participants reported eating vegetarian dinner alternatives more than once weekly, while 37 participants (41\%) reported eating such alternatives less than once monthly. The frequencies of consuming meat and seafood for dinner were quite similar (Table 5).

Table 5

Reported frequencies of intake of meat, fish or seafood and vegetarian alternatives for dinner, $n(\%)$.

\begin{tabular}{|c|c|c|c|c|c|c|c|}
\hline & Never & $\begin{array}{l}< \\
1 / \text { month }\end{array}$ & $\begin{array}{l}1- \\
3 / \text { month }\end{array}$ & 1/week & $\begin{array}{l}2- \\
3 / \text { week }\end{array}$ & $\begin{array}{l}4- \\
5 / \text { week }\end{array}$ & $\begin{array}{l}\text { 6- } \\
7 / \text { week }\end{array}$ \\
\hline Meat & 0 & 0 & $5(5.6)$ & $8(8.7)$ & $47(52.3)$ & $29(32.3)$ & $1(1.1)$ \\
\hline $\begin{array}{l}\text { Fish or } \\
\text { seafood }\end{array}$ & 0 & 0 & $4(4.4)$ & $6(6.6)$ & $54(59.3)$ & $25(27.5)$ & $2(2.2)$ \\
\hline Vegetarian & $\begin{array}{l}17 \\
(18.9)\end{array}$ & $20(22.2)$ & $25(27.8)$ & $\begin{array}{l}26 \\
(28.9)\end{array}$ & $2(2.2)$ & 0 & 0 \\
\hline
\end{tabular}

The median frequency of drinking milk was one portion $(\approx 2 \mathrm{dl})$ per day, and 56 participants $(60.9 \%)$ reported drinking milk that often, if not more. Seventeen participants (15.5\%) drank milk seldom or never. Yoghurt were used by 53 participants $(59.8 \%)$, however, only $10(10.9 \%)$ reported daily consumption. Cheese was consumed daily by 56 participants $(60.8 \%)$. 
Differences in biomarkers between participants reporting intake frequencies of different protein-rich food sources higher and lower than the median appear in Table 6. Participants with the highest intake of milk ( $p$ $=.014)$ and eggs $(p=.018)$ had lower levels of RBP than those with lower intake. Those analyses included participants with CRP levels of at least $5.0 \mathrm{mg} / \mathrm{L}$. However, sensitivity analyses did not alter the conclusions ( $p=.027$ for milk on RBP, $p=.018$ for eggs on RBP, all others non-significant).

Table 6

Albumin, prealbumin and $\mathrm{RBP}^{1}$ concentrations in relation to different protein sources $\geq$ or $<$ median intake.

\begin{tabular}{|c|c|c|c|c|c|c|c|}
\hline & & Albumin & $n$ & Prealbumin & $n$ & RBP & $n$ \\
\hline \multirow[t]{4}{*}{ Bread $^{2}$} & $\geq 4$ pieces/day & $44.2 \pm 2.7$ & 38 & $0.27 \pm 0.046$ & 39 & $0.052 \pm 0.012$ & 38 \\
\hline & $<4$ pieces/day & $44.5 \pm 2.4$ & 24 & $0.28 \pm 0.048$ & 23 & $0.056 \pm 0.010$ & 22 \\
\hline & Diff. & -0.27 & & -0.010 & & -0.0034 & \\
\hline & $p$ & .684 & & .417 & & .248 & \\
\hline \multirow[t]{4}{*}{ Milk } & $\geq 1$ portion/day & $44.1 \pm 2.6$ & 49 & $0.26 \pm 0.042$ & 50 & $0.052 \pm 0.010$ & 47 \\
\hline & $<1$ portion/day & $44.5 \pm 2.1$ & 31 & $0.28 \pm 0.048$ & 27 & $0.058 \pm 0.011$ & 29 \\
\hline & Diff. & -0.45 & & -0.02 & & -0.0064 & \\
\hline & $p$ & .424 & & .058 & & .014 & \\
\hline \multirow[t]{4}{*}{ Eggs } & $\geq 2-3 /$ week & $44.2 \pm 2.5$ & 53 & $0.26 \pm 0.044$ & 53 & $0.052 \pm 0.010$ & 52 \\
\hline & $<2-3 /$ week & $44.3 \pm 2.2$ & 27 & $0.28 \pm 0.046$ & 24 & $0.058 \pm 0.012$ & 24 \\
\hline & Diff. & -0.14 & & -0.020 & & -0.0064 & \\
\hline & $p$ & 0.805 & & 0.073 & & 0.019 & \\
\hline \multirow[t]{4}{*}{ Yoghurt } & $\geq 1-3$ portions/week & $44.2 \pm 2.6$ & 48 & $0.27 \pm 0.049$ & 46 & $0.054 \pm 0.011$ & 45 \\
\hline & $<1-3$ portions/week & $44.1 \pm 2.2$ & 31 & $0.27 \pm 0.049$ & 30 & $0.053 \pm 0.12$ & 30 \\
\hline & Diff. & 0.10 & & -0.0018 & & 0.0012 & \\
\hline & $p$ & .860 & & .869 & & .644 & \\
\hline \multirow[t]{4}{*}{ Cheese } & $\geq 1$ portion/day & $44.3 \pm 2.5$ & 46 & $0.26 \pm 0.039$ & 45 & $0.053 \pm 0.0095$ & 42 \\
\hline & $<1$ portion/day & $44.0 \pm 2.4$ & 33 & $0.28 \pm 0.053$ & 31 & $0.0545 \pm 0.013$ & 33 \\
\hline & Diff. & 0.3 & & -0.013 & & -0.0015 & \\
\hline & $p$ & .625 & & .240 & & .593 & \\
\hline
\end{tabular}


MNA screening was performed in 87 participants. Seven participants (8\%) were categorised as being at risk of malnutrition, whereas $80(92 \%)$ were not at risk. Participants at risk of malnutrition were significantly older than the others, with a mean age of $86.1 \pm 8.7$ years (mean diff. $=13.6$ years, $p<.001$ ) and had lower BMI (mean $\mathrm{BMI}=22.0 \pm 3.0$, mean diff. $=-4.7, p=.007$ ). Nevertheless, they did not have significantly different energy intake, protein intake or biomarker values.

\section{Discussion}

In our study, both energy and protein intake were lower than reported in the Troms $\varnothing$ study [24] and Norkost 3 study [17]. However, the participants in those studies were younger than the participants in the current study. The mean age in the Troms $\varnothing$ study was 57 years for women and 58 years for men, while the oldest age group reported in the Norkost 3 study was 60-70-year-olds. Protein intake tends to decline with age [25], despite increased need and higher recommendations. Nevertheless, protein intake in our study was in accordance with the Nordic recommendations for older adults [6].

Previous analyses of protein distribution in the current study sample revealed that protein was distributed well [19]. However, an even protein distribution during the day may not be beneficial if each meal does not contain enough protein to fully stimulate muscle protein synthesis. In our study, $28 \%$ of the participants did not eat 30 $\mathrm{g}$ of protein at any meal eaten during the day. In a Mexican study addressing the number of meals including at least $30 \mathrm{~g}$ of protein and risk of disability, $61 \%$ of participants reported eating zero meals with that amount of protein [12]. By comparison, Hone et al. [25] found that the mean number of meals with at least $30 \mathrm{~g}$ of protein per day among people 65 years and older was 0.96 , and that the number of meals with $\geq 30 \mathrm{~g}$ of protein significantly declined with age.

In our study, protein intake was skewed towards dinner, and very few participants ate the suggested threshold of $30 \mathrm{~g}$ of protein at meals other than dinner. A special feature of Norwegian dietary habits is that dinner is the only warm meal, whereas bread with some sort of spread is common for breakfast, lunch and the evening meal. Because dinnertime in Norway is quite early, normally between 4:00 and 6:00 p.m., many Norwegians also eat an evening meal. Skewed protein eating patterns have been identified by others $[11,25,26]$. However, compared with those studies, which revealed a pattern of low-protein breakfasts, medium-protein lunches and high-protein dinners, the pattern in our sample seemed to comprise one high-protein meal (i.e. dinner) and three low-protein ones. As a consequence, protein enhancement of the diet in Norway should focus on the low protein bread-based meals. Increased use of dairy products and protein-rich spreads could be potential targets for protein enrichment.

In our cross-sectional study of older adults in Norway, we could not determine associations between biomarkers of protein and protein intake, number of meals with more than $30 \mathrm{~g}$ of protein or frequency of consumption of bread, yoghurt or cheese. Contrary to our expectations, we identified a negative association between RBP and consuming milk and eggs. However, because RBP has a short half-life (i.e. $<1 \mathrm{~d}$ ), it reflects only acute changes in protein intake. Data concerning protein sources represented the past 6 months; thus, any associations with RBP may be random despite their significance. 
The lack of associations between biomarkers and nutrition may relate to the fact that participants were healthy and had a sufficient food intake. Their mean BMI was 26.3 , which is fairly less than the study sample of the Troms $\varnothing$ study including 3286 participants [27]. In the general population, a BMl exceeding 25.0 would be regarded as overweight. However, due to age-related changes in lean body mass, a BMI between 22.0 and 27.0 is recommended for older adults (i.e. $\geq 65$ years old) in Norway's national guidelines for the treatment and prevention of malnutrition [20]. BMls less than 22.0 are associated with higher mortality in older adults, whereas overweight is not [28, 29]. Kvamme et al. [27] also found that health-related quality of life was significantly higher in moderately overweight individuals.

Risk of malnutrition, as measured with MNA, was not associated with energy intake, protein intake or biomarkers in our study. In the study of Zhang et al. [30], albumin and prealbumin were significantly lower among individuals evaluated to be at risk of malnutrition by the Mini Nutritional Assessment (MNA) than among those not at risk. In a cross-sectional study conducted in Italy in 2006, albumin, prealbumin and RBP were all shown to correlate with fat-free body mass in healthy underweight, normal weight and overweight older adults [23]. Low serum values for those visceral proteins, even within the reference range, could suggest poor nutritional status [23]. However, the number of participants at risk of malnutrition in our study was low $(n=7)$, and we emphasize that they were categorised as being at risk of malnutrition, not as having malnutrition. This MNA score is an opportunity to prevent malnutrition, even before the subjects show clinical signs. Preventing malnutrition can imply major cost savings for communities-in Norway, some 800 million NOK annually, or approximately $1.0 \%$ of all costs at hospitals [31].

Our protein intake data came from a single 24-h recall, which was a prominent weakness of our study. However, because the recall was performed in the participants' homes, it was possible to gain accurate measures, as participants could present actual foods or their packaging, measure amounts in the plates and/or cups used and/or compare portion sizes with images in the portion sizes booklet. Thus, we believe that the recall data represent the actual daily intake quite well.

\section{Conclusions}

This cross-sectional study of dietary habits and biomarkers of protein in older adults could not demonstrate any significant associations between the nutrition factors and biomarkers. However, the study shows that despite a daily protein intake in accordance with guidelines, the participants eat few protein rich meals. To our knowledge, no previous studies have examined the per-meal intake and the number of meals with at least $30 \mathrm{~g}$ of protein in a Norwegian population. It was also among the first to examine associations between protein eating patterns and visceral proteins. Future study should collect dietary data on protein intake per meal in order to gain knowledge about eating patterns and their possible relation to health effects.

\section{Declarations}

\section{Ethics approval and consent to participate}

All subjects gave their informed oral and written consent for inclusion before they participated in the study, which was conducted in accordance with the Declaration of Helsinki and approved by the Regional 
Committee on Ethics in Medical Research (REK) in Mid-Norway in September 2016 with the registration ID 2016/1152. Changes in inclusion criteria were approved in August 2017.

\section{Consent for publication}

Not applicable

\section{Availability of data and materials}

The datasets generated and/or analysed during the current study are not publicly available due to privacy restrictions but are available from the corresponding author on reasonable request.

\section{Competing interests}

The authors declare that they have no competing interests.

\section{Funding}

The project is funded by a general PhD grant from Molde University College. Blood analyses are funded by The Research Council of Norway, Program for Regional R\&D and Innovation (VRI).

\section{Authors' contributions}

LKN is the PhD research fellow responsible for the study. LKN, AMMR, LD and IM developed the study design. LKN performed the statistical analyses. LKN drafted the manuscript and AMMR, IM and LD took part in the writing process. All authors read and approved the final version of the manuscript.

\section{Acknowledgements}

We would like to express our very great appreciation to the participants in the study, to the healthcare staff who recruited the first 16 participants, and to public relations adviser Jan Ragnvald Eide, local media, senior citizen associations, and others who participated in further recruitment of participants. We also want to acknowledge the local GPs and laboratory staff who took the blood samples and laboratories at Molde hospital and St. Olav hospital for analysis. A special 'thank you' goes to Tore Skei at St. Olav hospital for assistance with laboratory reports.

\section{References}

1. Wysokinski A, Sobow T, Kloszewska I, Kostka T. Mechanisms of the anorexia of aging-a review. Age (Dordr). 2015;37:9821.

2. Bales CW, Locher JL, Saltzman E. Handbook of Clinical Nutrition and Aging. New York: Springer; 2014.

3. Bergland A, Meaas I, Debesay J, Brovold T, Jacobsen EL, Antypas K, et al. Associations of social networks with quality of life, health and physical functioning. Eur J Physiother. 2016;18:78-88.

4. Schorr AV, Yehuda I, Tamir S. Loneliness, malnutrition and change in subjective age among older adults during COVID-19 pandemic. Int J Environ Res Public Health. 2021;18:106. 
5. Borkent JW, Beelen J, Linschooten JO, Roodenburg AJC, Schueren MAEDVD. The ConsuMEER study: a randomised trial towards the effectiveness of protein-rich ready-made meals and protein-rich dairy products in increasing protein intake of community-dwelling older adults after switching from selfprepared meals towards ready-made meals. J Nutr Sci. 2019;8:e30.

6. Nordic Council of Ministers. Nordic nutrition recommendations 2012: integrating nutrition and physical activity. Copenhagen: Nordic Council of Ministers; 2014.

7. Robinson S, Granic A, Sayer AA. Nutrition and muscle strength, as the key component of sarcopenia: an overview of current evidence. Nutrients. 2019;11:2942.

8. Bollwein J, Diekmann R, Kaiser MJ, Bauer JM, Uter W, Sieber CC, et al. Distribution but not amount of protein intake is associated with frailty: a cross-sectional investigation in the region of Nurnberg. Nutr J. 2013;12:109.

9. Hojfeldt G, Nishimura Y, Mertz K, Schacht SR, Lindberg J, Jensen M, et al. Daily protein and energy intake are not associated with muscle mass and physical function in healthy older individuals-a cross-sectional study. Nutrients. 2020;12:2794.

10. Nygard LK, Dahl L, Mundal I, Benth JS, Rokstad AMM. Protein intake, protein mealtime distribution and seafood consumption in elderly Norwegians: associations with physical function and strength. Geriatrics (Basel). 2020;5:100.

11. Murphy $\mathrm{CH}$, Oikawa SY, Phillips SM. Dietary protein to maintain muscle mass in aging: a case for permeal protein recommendations. J Frailty Aging. 2016;5:49-58.

12. Gaytan-Gonzalez A, Ocampo-Alfaro MJ, Torres-Naranjo F, Arroniz-Rivera M, Gonzalez-Mendoza RG, GilBarreiro $\mathrm{M}$, et al. The consumption of two or three meals per day with adequate protein content is associated with lower risk of physical disability in mexican adults aged 60 years and older. Geriatrics (Basel). 2020;5:1.

13. Wall BT, Cermak NM, van Loon LJ. Dietary protein considerations to support active aging. Sports Med. 2014;44(Suppl 2):185-94.

14. Coultate TP. Food: the chemistry of its components. 6th ed. Cambridge: Royal Society of Chemistry; 2016.

15. Ross AC, Caballero B, Cousins RJ, Tucker KL, Ziegler TR. Modern nutrition in health and disease. Philadelphia: Wolters Kluwer Health; 2012.

16. Aadland EK, Lavigne C, Graff IE, Eng O, Paquette M, Holthe A, et al. Lean-seafood intake reduces cardiovascular lipid risk factors in healthy subjects: results from a randomized controlled trial with a crossover design. Am J Clin Nutr. 2015;102:582-92.

17. Totland TH, Melnæs BK, Lundberg-Hallén N, Helland-Kigen KM, Lund-Blix NA, Myhre JB, et al. Norkost 3: en landsomfattende kostholdsundersøkelse blant menn og kvinner i Norge i alderen 18-70 år, 20102011. Oslo: Norwegian Directorate of Health; 2012.

18. Keller U. Nutritional laboratory markers in malnutrition. J Clin Med. 2019;8:775.

19. Nygard LAK, Mundal I, Dahl L, Benth JS, Rokstad AMM. Nutrition and physical performance in older people-effects of marine protein hydrolysates to prevent decline in physical performance: a randomised controlled trial protocol. BMJ Open. 2018;8:e023845. 
20. Norwegian Directorate of Health. IS-1580: nasjonale faglige retningslinjer for forebygging og behandling av underernæring. Oslo: Norwegian Directorate of Health; 2010.

21. Adamson AJ, Collerton J, Davies K, Foster E, Jagger C, Stamp E, et al. Nutrition in advanced age: dietary assessment in the Newcastle 85 + study. Eur J Clin Nutr. 2009;63(Suppl 1):6-18.

22. Guigoz $Y$, Jensen $G$, Thomas $D$, Vellas $B$. The mini nutritional assessment (MNA®) review of the literature-what does it tell us?/discussion. J Nutr Health Aging. 2006;10:466-85. discussion 485-7.

23. Sergi G, Coin A, Enzi G, Volpato S, Inelmen EM, Buttarello M, et al. Role of visceral proteins in detecting malnutrition in the elderly. Eur J Clin Nutr. 2006;60:203-9.

24. Lundblad MW, Andersen LF, Jacobsen BK, Carlsen MH, Hjartaker A, Grimsgaard S, et al. Energy and nutrient intakes in relation to national nutrition recommendations in a Norwegian population-based sample: the Tromso study 2015-16. Food Nutr Res. 2019;63:1-10.

25. Hone M, Nugent AP, Walton J, McNulty BA, Egan B. Habitual protein intake, protein distribution patterns and dietary sources in Irish adults with stratification by sex and age. J Hum Nutr Diet. 2020;33:465-76.

26. Berner LA, Becker G, Wise M, Doi J. Characterization of dietary protein among older adults in the United States: amount, animal sources, and meal patterns. J Acad Nutr Diet. 2013;113:809-15.

27. Kvamme JM, Olsen JA, Florholmen J, Jacobsen BK. Risk of malnutrition and health-related quality of life in community-living elderly men and women: the Tromso study. Qual Life Res. 2011;20:575-82.

28. Gulsvik AK, Thelle DS, Mowe M, Wyller TB. Increased mortality in the slim elderly: a 42 years follow-up study in a general population. Eur J Epidemiol. 2009;24:683-90.

29. Winter JE, Maclnnis RJ, Wattanapenpaiboon N, Nowson CA. BMl and all-cause mortality in older adults: a meta-analysis. Am J Clin Nutr. 2014;99:875-90.

30. Zhang Z, Pereira SL, Luo M, Matheson EM. Evaluation of blood biomarkers associated with risk of malnutrition in older adults: a systematic review and meta-analysis. Nutrients. 2017;9:829.

31. Juul $\mathrm{H}$. Forebygging og behandling av underernæring-oppgave i kostnad nytte analyse. Oslo: University of Oslo; 2010. 